\title{
Ligand-independent activation of progestin receptors: relevance for female sexual behaviour
}

\author{
Anthony P. Auger \\ Department of Physiology, University of Maryland, Baltimore School of Medicine, \\ Baltimore, MD 21201, USA
}

\begin{abstract}
Traditionally, steroid receptors were believed to be activated only by ligand binding; however, recent studies indicate that steroid receptors can also be activated by mechanisms that do not require ligand, referred to as ligand-independent activation. Specifically, progestin receptors can be activated in vitro and in vivo after treatment with neurotransmitters, such as dopamine, in the absence of progesterone. Furthermore, mating-related stimuli can also lead to ligand-independent activation of progestin receptors in female rat brain. This finding indicates that environmental stimuli can influence steroid receptor-dependent processes in the absence of circulating hormone. This review focuses on studies indicating that progestin receptors can be activated in the absence of progesterone to influence neuronal response and sexual behaviour in rodents.
\end{abstract}

Ovarian steroid hormone receptors influence a variety of physiological and behavioural processes in many species, including humans. It had been assumed that intracellular steroid receptors were activated only by cognate ligands binding to a ligand-binding domain located on the receptor, referred to as ligand- or steroid-dependent activation. However, steroid receptors can be activated in vitro in the absence of steroid (Power et al., 1991a; Aronica and Katzenellenbogen, 1993; Kazmi et al., 1993), that is, by ligand- or steroid-independent activation. More importantly, ligand-independent activation of steroid receptors (that is, progestin receptors) within the brain can influence reproductive behaviour in rodents. This review focuses on recent findings which indicate that some somatosensory cues normally experienced by females, such as those associated with sexual contact with males, can activate progestin receptors to influence both neuronal response and oestrous behaviour in a ligand-independent manner.

\section{Hormonal requirements for the induction of sexual behaviour}

During the oestrous cycle in rats, sexual behaviour is dependent upon an increase in serum oestradiol followed by an increase in progesterone concentrations. Sexual behaviour is abolished by ovariectomy, and reinstated by the injection of oestradiol followed 1 or 2 days later by progesterone. Treatment with oestradiol alone can induce some aspects of sexual behaviour, such as receptivity (for example, lordosis); however, oestradiol followed by progesterone administration induces the full complement of proceptive behaviours that occur during normal oestrus,

Email: aauge001@umaryland.edu such as ear wiggling, hopping and darting behaviour (Blaustein and Olster, 1989). This finding indicates that both oestradiol and progesterone are critical for the occurrence of normal oestrous behaviour. Oestradiol and progesterone are secreted from both the ovaries and the adrenal glands (Shaikh and Shaikh, 1975). Steroid hormone secretion from the adrenal glands appears to be important for the normal timing of sexual behaviour in rats, as stress resulting from sham ovariectomy advances, and stress resulting from adrenalectomy delays, the onset of oestrous behaviour. In addition, the small increase in solicitational behaviour induced by oestradiol treatment alone is blocked by adrenalectomy. Therefore, sexual behaviour is influenced by secretion of steroid hormones not only from the ovary, but also from the adrenal glands.

\section{Behavioural and physiological changes associated with mating stimulation}

When mating occurs, the female rat experiences a variety of somatosensory and olfactory stimuli from the male that further influences female sexual behaviour (Pfaff et al., 1994). For example, ovariectomized rats primed with low doses of oestradiol exhibit reduced lordosis in the presence of a sexually active male; however, repeated exposure of ovariectomized oestradiol-primed female rats to males will induce increased lordosis (Hardy and Debold, 1973). The increase in lordosis owing to repeated mating of oestradiolprimed female rats occurs within an hour, and this behavioural phenomenon is not dependent upon the adrenal glands (Foreman and Moss, 1977). Therefore, mating-related stimuli increase sexual receptivity in the absence of circulating progesterone. It is not clear which somatosensory and olfactory cues are important for mediat- 


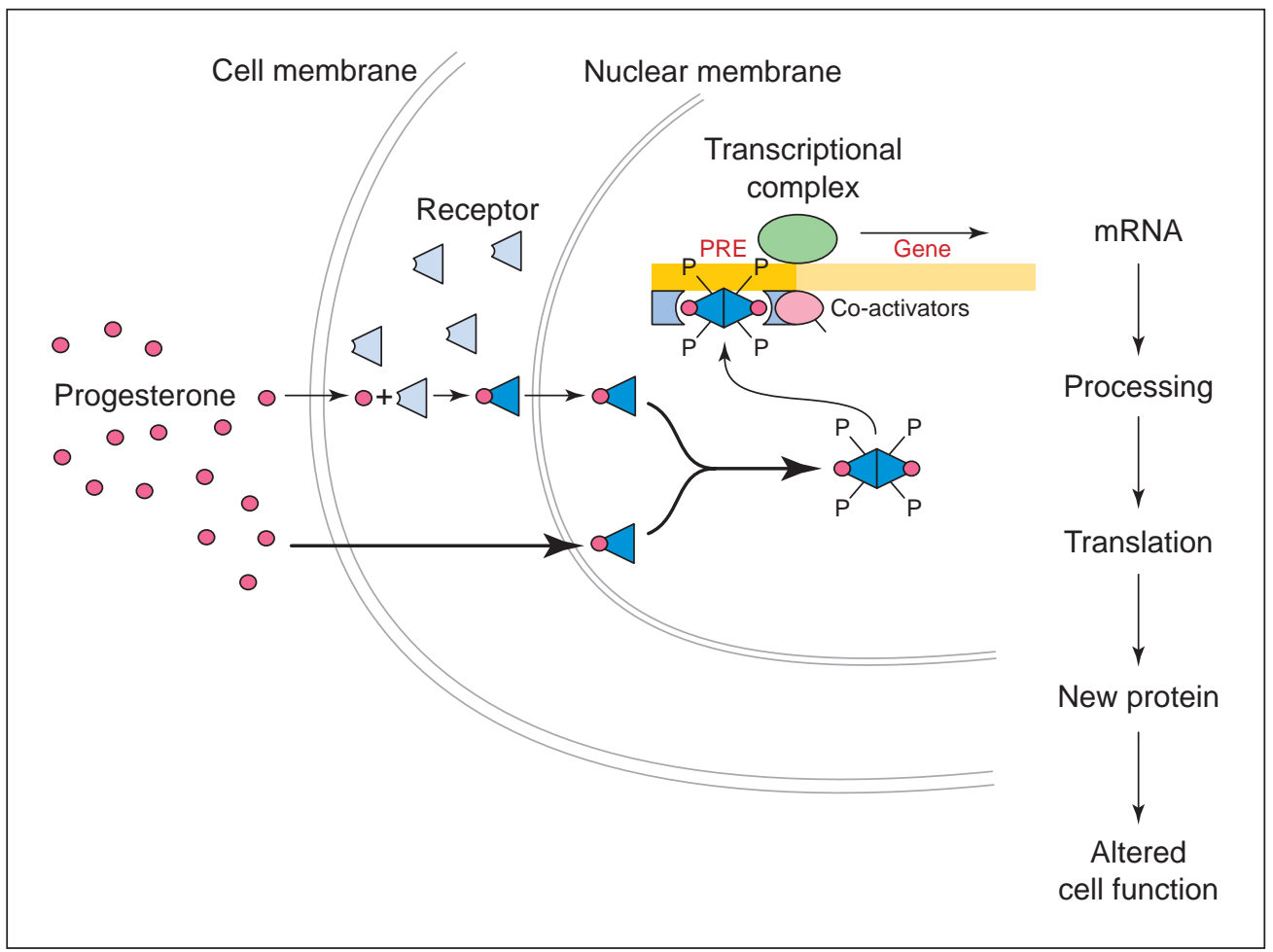

Fig. 1. Classical mechanism for activation of progestin receptors by progesterone. Progesterone passes through the cell membrane and binds to progestin receptors either in the cytoplasm or the nucleus. Ligandbound receptors translocate into the nucleus, where they bind to another ligand-receptor complex. This dimer complex then binds to a response element on DNA, and interacts with nuclear receptor coregulatory proteins to alter gene transcription. PRE: progestin response element; P: phosphorylated site.

ing these increases in sexual receptivity. One potential somatosensory pathway may be via stimulation of the flank and perineum, which occurs when the male clasps the female during copulation. Stimulation of these regions appears to be critical for the elicitation of lordosis (Pfaff et al., 1994).

Another pathway mediating mating-induced increases in sexual receptivity may be via vaginal-cervical stimulation (VCS). VCS can induce many different behavioural and endocrine changes in female rats, including increased lordosis, pseudopregnancy, and termination of sexual receptivity. VCS increases 2 -deoxy-D-glucose uptake, an index of increased metabolism, within the medial preoptic area, bed nucleus of the stria terminalis and midbrain central gray (Allen et al., 1981). Sensory information provided by VCS gains access to the central nervous system via pudendal, pelvic, hypogastric and vagus nerves.

\section{Ligand-dependent activation of progestin receptors}

Steroid hormones influence sexual behaviour by binding to intracellular steroid receptors (Blaustein and Olster, 1989), although some effects may be the result of steroid hormone interaction with membrane receptors. After ligand binding, steroid receptors undergo a conformational change that allows the ligand-receptor complex to bind to a hormone response element (HRE) on DNA. Although steroid receptors may bind to DNA as a monomer, receptor dimers are more stable and bind more efficiently to HREs. Once the steroid-receptor complex binds to DNA, it can interact with various combinations of co-regulatory proteins to influence genomic transcription (McKenna et al., 1999) (Fig. 1). Coregulatory proteins that increase steroid receptor action are called co-activators, and those that decrease steroid receptor action are called co-repressors. Interaction of steroid receptors with nuclear receptor co-activators appears to be important for steroid receptor action in vitro (McKenna et al., 1999), as well as within the brain (Auger et al., 2000a). Some cellular outcomes of steroid hormone action within the brain are changes in second messenger systems, inducible transcription factors, peptide receptors, and neurotransmitter synthesis and release.

\section{Neuroanatomical distribution of oestrogen and progestin receptors}

In rat brain, gonadal steroid receptor-containing neurones are heterogeneously expressed in particular neuroanatomical sites (Pfaff and Keiner, 1973). There are at least two 


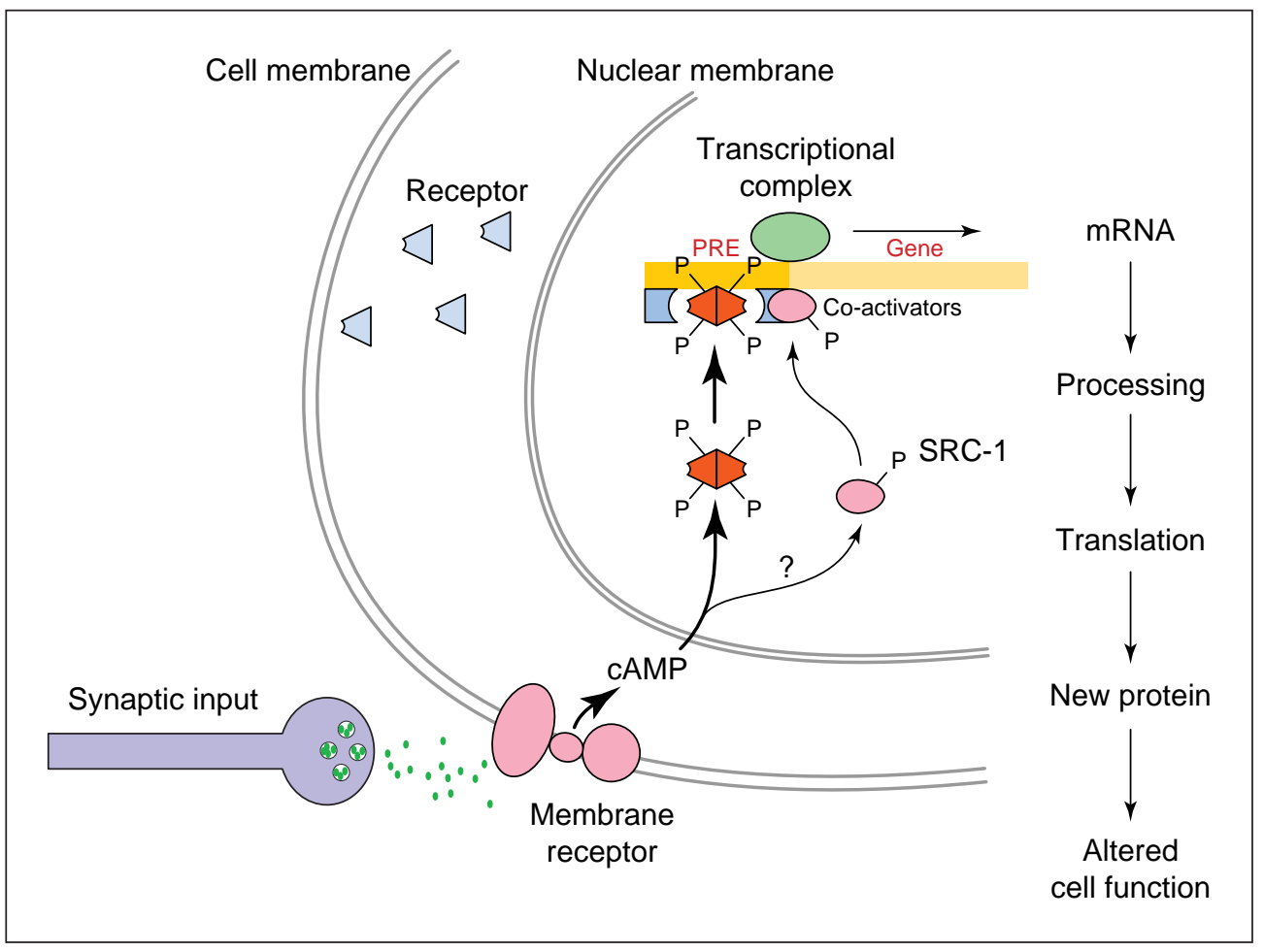

Fig. 2. Ligand-independent activation of progestin receptors. Neurotransmitters (for example, dopamine) or peptides stimulate membrane receptors, resulting in increased phosphorylation of proteins. These newly phosphorylated proteins (for example, steroid receptor co-activator 1 (SRC-1)) result in the recruitment of progestin receptors to form an active transcriptional complex, which can regulate gene expression in the absence of progesterone. PRE: progestin response element; P: phosphorylated site.

types of oestrogen receptor: oestrogen receptor $\alpha(E R \alpha)$ and oestrogen receptor $\beta$ (ER $\beta)$. ER $\beta$ has a high degree of sequence similarity with $E R \alpha$ (Kuiper et al., 1996). Although small amounts of $E R \alpha m R N A$ can be found in many regions of female rat brain, the greatest amounts occur within the medial preoptic area, bed nucleus of the stria terminalis, ventromedial hypothalamus, arcuate nucleus, amygdala, lateral septum and some regions of the midbrain (Simerly et al., 1990; Shughrue et al., 1997). The distribution of ERß mRNA in the forebrain appears to have an overlapping distribution with ER $\alpha$ mRNA with some important exceptions: ER $\beta$ mRNA appears not to be present within the ventromedial hypothalamus and in smaller amounts than $E R \alpha m R N A$ within the arcuate nucleus; whereas, ER $\beta$ mRNA is present in high concentrations within the paraventricular nucleus of the hypothalamus and hippocampus compared with ER $\alpha$ mRNA (Shughrue et al., 1997).

Although progestin-binding sites are found throughout female rat brain, treatment with oestradiol increases progestin receptor concentrations primarily within the preoptic area and mediobasal hypothalamus (Blaustein and Olster, 1989). Oestradiol-induced progestin receptorimmunoreactivity in rats is expressed within the preoptic area, the ventromedial hypothalamus, the arcuate nucleus and a small number of cells in the posterodorsal medial amygdala. Expression of progestin receptors occurs in two forms, progestin receptor A and progestin receptor B (Conneely et al., 1987). These two isoforms are expressed differentially within the brain during development (Kato et al., 1993) and over the oestrous cycle (Guerra-Araiza et al., 2000). As progestin receptor $A$ and $B$ differ in the $N$ terminal sequence, which conveys gene activation (Tora et al., 1988), these isoforms are functionally distinct (MulacJericevic et al., 2000). Therefore, differential activation of progestin receptor isoforms can lead to different functional outcomes.

\section{Ligand-independent activation of progestin receptors in vitro}

Although steroid hormones influence a variety of behavioural and physiological processes, the activation of nuclear steroid receptors is ultimately the most important factor in most of these outcomes. Therefore, attention should be focused on how steroid receptor activity is regulated within the brain. Oestrogen receptors (Aronica and Katzenellenbogen, 1993) and progestin receptors (Power et al., 1991a) can be activated in vitro in the absence 
of their respective ligand. For example, treatment with 8bromo-cyclic adenosine monophosphate (8-Br cAMP), an activator of protein kinase A (PKA), which phosphorylates serine or threonine residues, activates progestin receptors in vitro in the absence of progesterone (Denner et al., 1990; Kazmi et al., 1993). Chicken ovalbumin upstream promoter transcription factor (COUP-TF) is activated in vitro by the neurotransmitter dopamine (Power et al., 1991b). In addition, progestin receptors can be activated in vitro by neurotransmitters, such as dopamine (Power et al., 1991a) (Fig. 2).

Although some studies indicate that progestin receptors are phosphorylated in different manners by liganddependent versus ligand-independent pathways (Bai et al., 1997), phosphorylation of progestin receptors via these two pathways may not differ functionally (Chauchereau et al., 1994; Bai et al., 1997). Furthermore, phosphorylation of progestin receptors by ligand-independent pathways is not critical for progestin receptor activation (Bai et al., 1997). This finding indicates that progestin receptors are not the target of phosphorylation by ligand-independent pathways. Indeed, the targets of phosphorylation by 8 -Br cAMP may be nuclear receptor co-activators, such as steroid receptor co-activator 1 (SRC-1) (Rowan et al., 2000). Treatment of COS-1 cells with 8-Br cAMP leads to increased phosphorylation of SRC-1 at threonine-1179 and serine-1185. Blocking the phosphorylation of threonine-1179 and serine-1185 inhibits the interaction of SRC-1 with another CO-activator, CAMP response element binding protein (CREB)-binding protein (CBP). Preventing the interaction of SRC-1 with CBP impedes the formation of an active transcriptional complex (Rowan et al., 2000), indicating that the phosphorylation of SRC-1 is a critical step for the formation of an active transcriptional complex associated with progestin receptors. Since SRC-1 was first characterized, many co-activators have been reported, such as SRC-2, SRC-3 and androgen receptor co-activator 70 (McKenna et al., 1999). Phosphorylation of target proteins other than progestin receptors, such as nuclear receptor coactivators, allows for more combinations of phosphorylated proteins to be recruited into a transcriptional complex. One outcome of having various combinations of phosphorylated proteins within a transcriptional complex might be to provide distinct functional consequences. Thus, it is possible that ligand-activated progestin receptors function in a more discrete manner than do ligand-independent activated progestin receptors, as a result of differential phosphorylation of nuclear receptor co-regulatory proteins.

Further support for the idea that ligand versus ligandindependent pathways function to alter gene expression or behaviour differentially comes from examining the phosphorylation of the progestin receptor isoforms by $8-\mathrm{Br}$ CAMP. The progestin receptor $A$ isoform is more sensitive to 8-Br cAMP-mediated phosphorylation than is the progestin receptor B isoform (Kazmi et al., 1993). As progestin receptor isoforms are involved in different functional outcomes, increasing ligand versus ligand-independent pathways may alter one isoform preferentially, leading to a unique functional outcome. Alternatively, ligand-independent pathways may function to enhance ligand activation of progestin receptors. This possibility is supported by data indicating that combined treatment of steroid with a phosphorylation activator leads to a greater trans-activational response of progestin receptors than that observed with treatment of either steroid or phosphorylation activator alone (Edwards et al., 1993; Kazmi et al., 1993).

\section{Ligand-independent activation of progestin receptors in vivo}

Converging evidence indicates that ligand-independent activation of progestin receptors is important for female sexual behaviour. Dopamine increases lordosis when infused into the medial preoptic area or ventromedial hypothalamus of oestrone-primed female rats (Foreman and Moss, 1979). As dopamine leads to activation of progestin receptors in tissue culture (Power et al., 1991a) and increases sexual behaviour in oestrogen-primed females rats, it was hypothesized that dopamine increases sexual behaviour via ligand-independent activation of progestin receptors (Mani et al., 1994a). Infusion of the dopamine $\left(D_{1}\right)$ receptor agonist SKF 38393 into the third ventricle of oestradiol-primed rats increased lordosis, and prior treatment with progestin antagonists blocked dopamine facilitation of lordosis. Dopamine facilitation of sexual behaviour was independent of adrenal steroid secretions, as these findings were replicated in dexamethasone-suppressed female rats. This finding indicates that pharmacological treatment with dopamine can lead to the activation of progestin receptors in the absence of progesterone. Numerous other factors have been found that appear to activate progestin receptors in a similar manner to influence lordosis in oestradiol-primed rats. For example, gonadotrophin releasing hormone, prostaglandin $E_{2}$, dibutyryl CAMP, nitric oxide, 8-bromo-cGMP and cocaine all increase lordosis in oestradiol-primed female rats, and these increases are blocked by the progestin antagonist RU486 (Mani et al., 1994b; Beyer et al., 1997; Chu et al., 1999). It is conceivable that additional neurotransmitters or peptides will be found that activate progestin receptors to influence sexual behaviour, as factors that increase phosphorylation of proteins may result in increased lordosis in oestradiol-primed female rats. Further cross-talk between dopamine, progestin receptors and the cannibinoid $\Delta^{9}$. tetrahydrocannabinol (THC) has been described in the regulation of female sexual behaviour (Mani et al., 2001). As with dopamine, infusion of THC into the third ventricle of oestradiol-primed rats increased lordosis, and prior treatment with progestin antagonists blocked THC facilitation of lordosis (Mani et al., 2001). Both progesterone- and THC-facilitated lordosis can be blocked by infusion of antisense oligodeoxynucleotides that reduce the expression of either progestin receptors or dopamine $D_{1}$ receptors (Mani et al., 2001), indicating that pathways leading to 
ligand-independent activation of progestin receptors are important in ligand activation of progestin receptors. That is, the phosphorylation of target proteins that are normally activated by ligand-independent mechanisms are likely to be involved in interacting with ligand-activated progestin receptors.

\section{Influence on behaviour of mating-related stimuli that activate progestin receptors}

A major question concerning ligand-independent activation of progestin receptors is: when is this mechanism activated under normal circumstances? As described above, sexual receptivity is increased in oestradiol-primed female rats during interaction with a sexually active male, and this increase occurs in the absence of serum progesterone. Dopamine is released during mating stimulation (Matuszewich et al., 2000) and is implicated in the activation of progestin receptors in the absence of progesterone (Mani et al., 1994a). Therefore, sexual receptivity may be increased before a surge in progesterone in the presence of a sexually receptive male. For example, ovariectomized-adrenalectomized, oestradiolprimed female rats show increased sexual behaviour in a repeated-mating test with a sexually active male. Each mating test takes $15 \mathrm{~min}$ and is separated by a $15 \mathrm{~min}$ nonexposure period. Sexual receptivity in control-treated female rats is increased by the third and fourth mating test; however, this increase is inhibited completely in rats injected with the progestin antagonist RU486 (Auger et al., 1997). Therefore, progestin receptors appear to be important in mediating mating-induced increases in sexual behaviour even in the absence of circulating progesterone. This finding is consistent with the idea that mating interaction can lead to ligand-independent activation of progestin receptors to alter behaviour. The specific cue responsible has not yet been identified, but it appears that some somatosensory information provided by VCS may be involved in ligand-independent activation of progestin receptors. Manual VCS plus flank-perineum stimulation reliably induces lordosis at the time of stimulation. There is no difference in lordosis quotients between rats pretreated with the progestin antagonist RU486 and rats treated with oil vehicle, indicating that a neuronal component that is not dependent upon progestin receptors is activated by VCS. However, RU486-treated female rats placed in an arena with a sexually active male 15 min after VCS show lower sexual receptivity than do the oil-treated controls (Auger et al., 1997). Although RU486-treated females have the capacity to show a similar degree of lordosis to that displayed by oil-treated rats receiving VCS, RU486-treated females show less sexual behaviour in the presence of a male. Furthermore, females that are masked to prevent intromissions do not show increased sexual receptivity after repeated mating, indicating that VCS is required for matinginduced lordosis (Bennett et al., 2001). Taken together, these data indicate that increased sexual receptivity in response to somatosensory information provided by VCS during mating is the result of ligand-independent activation of progestin receptors. As mating stimuli rapidly increase (Bennett et al., 2001) and subsequently decrease (Reading and Blaustein, 1984) lordosis in oestradiol-primed female rats, it is possible that mating-induced activation of progestin receptors is involved in the normal timing of sexual receptivity.

\section{Neuroanatomical sites involved in mating-induced activation of progestin receptors}

One method for investigating the site of mating-induced activation of progestin receptors in the rat brain is to examine neuronal responses to mating-related stimuli. A widely used technique to identify neurones that respond to particular stimuli is the immunocytochemical detection of immediate early gene proteins (also known as inducible transcription factors), such as Fos. VCS increases the expression of Fos protein in a variety of brain regions, including the medial preoptic area, ventromedial hypothalamus, dorsomedial hypothalamus, bed nucleus of the stria terminalis, amygdala and the anterior-periventricular thalamic nucleus (Pfaus et al., 1993; Tetel et al., 1993; Auger et al., 1996). Furthermore, VCS increases Fos expression in progestin receptor-containing neurones within the medial preoptic area, arcuate nucleus and the ventromedial hypothalamus (Auger et al., 1996). More importantly, prior treatment with the progestin antagonist RU486 reduces VCS-induced Fos expression only in areas such as the medial preoptic area and the ventromedial hypothalamus containing high concentrations of progestin receptors (Auger et al., 1997). VCS-induced Fos immunoreactivity was not reduced by RU486 in areas such as the amygdala or the anterior-periventricular thalamic nucleus containing little to no progestin receptor immunoreactivity. The reduction of VCS-induced Fos expression by RU486 is independent of circulating progesterone, as it occurs in ovariectomized-adrenalectomized oestradiol-primed female rats (Auger et al., 1997). This finding indicates that some cellular responses associated with VCS are mediated via progestin receptors, as blocking progestin receptor activation impedes VCS-induced Fos expression.

Further evidence that VCS influences processes involved in ligand-independent activation of progestin receptors within steroid receptor-containing areas comes from examining a dopamine- and cyclic AMP-regulated phosphoprotein, DARPP-32 $\left(M_{r}=32\right.$ 000). DARPP-32 is phosphorylated on threonine34 in response to activation of dopamine $D_{1}$, but not $\mathrm{D}_{2}$, receptors (Walaas and Greengard, 1984). DARPP32 is involved in mediating both progesterone- and dopamine-facilitated lordosis in oestradiol-primed female mice, indicating that DARPP-32 is important for ligandindependent activation of progestin receptors (Mani et al., 2000). Oestradiol-primed mice with a targeted disruption of DARPP-32 do not show increased sexual receptivity after treatment with either progesterone or dopamine. One mechanism by which the phosphorylation of DARPP-32 


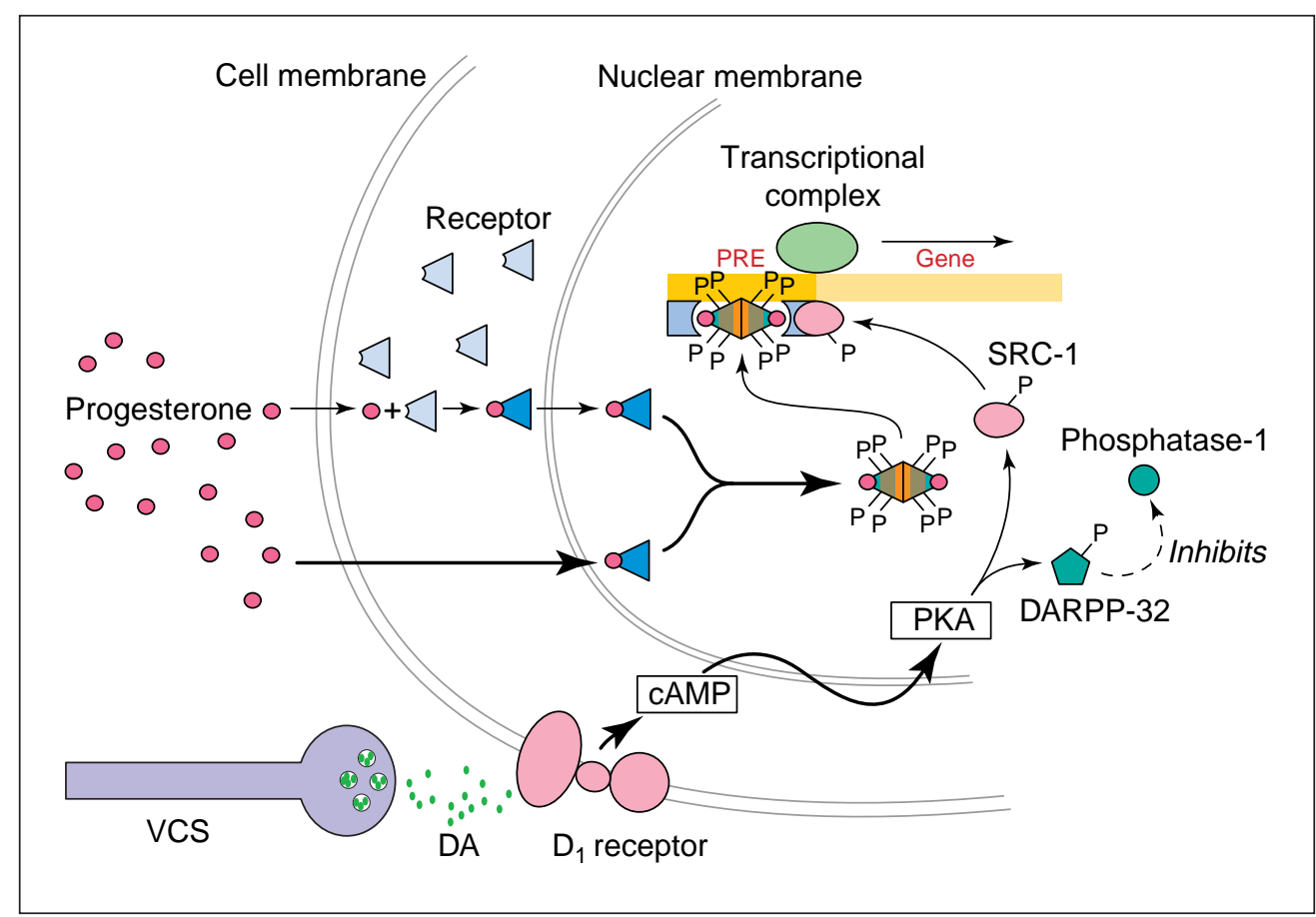

Fig. 3. Model for mating-induced activation of progestin receptors. Mating stimuli (for example vaginal-cervical stimulation (VCS)) cause the release of dopamine (DA) in progestin receptor-rich areas, such as the medial preoptic area and ventromedial hypothalamus. Dopamine, acting on dopamine $\mathrm{D}_{1}$ receptors, increases the activity of CAMP and protein kinase A (PKA), leading to increased phosphorylation of proteins, such as steroid receptor co-activator 1 (SRC-1) and dopamine- and cyclic AMP-regulated phosphoprotein (DARPP-32). Phosphorylation of DARPP-32 leads to the inhibition of phosphatase-1, which dephosphorylates proteins, and thereby potentiates the phosphorylation of other proteins. Phosphorylation of SRC-1 leads to the recruitment of progestin receptors and other coactivators to form a transcriptional complex, which can increase gene transcription and alter behaviour. P: phosphorylated site; PRE: progestin response element.

may influence ligand-independent activation of progestin receptors is by allowing increased phosphorylation of other cellular proteins by inhibiting protein phosphatase 1 , which is involved in dephosphorylating proteins. These data support the contention that proteins involved in ligandindependent activation of progestin receptors also mediate ligand activation of progestin receptors.

An antibody that detects the phosphorylated form of DARPP-32 was used to examine female rat brains $1 \mathrm{~h}$ after receiving VCS. The number of cells expressing phosphoDARPP-32 immunoreactivity was increased within the medial preoptic area and ventromedial hypothalamus (Meredith et al., 1998), indicating that some of the somatosensory stimuli associated with VCS may influence cells within the ventromedial hypothalamus and medial preoptic area via a dopaminergic mechanism. Consistent with the location of DARPP-32, dopamine $D_{1}$ receptor binding (Boyson et al., 1986), $\mathrm{D}_{1}$ receptor immunoreactivity (Levey et al., 1993), and $D_{1}$ mRNA (Zhou et al., 1999) have been localized within the amygdala, preoptic area and ventromedial hypothalamus. Therefore, VCS may activate progestin receptors to influence neuronal responses and behaviour via a dopaminergic pathway (Fig. 3).

\section{Ligand-independent activation of progestin receptors: regulation of gonadotrophin secretion}

Ligand-independent activation of progestin receptors may also be involved in the release of FSH (Knox et al., 1996) and $\mathrm{LH}$ (Levine, 1997) in female rats. Oestradiol increases the release of $\mathrm{FSH}$ and $\mathrm{LH}$ in ovariectomized female rats, and treatment with progestin antagonists blocks these increases (Knox et al., 1996; Levine, 1997). It is not clear how oestradiol mediates these increases, but one pathway may involve nitric oxide. Oestradiol increases nitric oxide synthase, and nitric oxide stimulates CGMP, which has been shown to activate progestin receptors (Chu et al., 1999). Therefore, it is possible that oestradiol influences the release of LH via stimulation of nitric oxide-cGMP pathways. Alternatively, oestradiol may act via a dopaminergic mechanism. For example, oestradiol treatment increases the expression of $D_{1}$ dopamine receptors in neonatal rat 


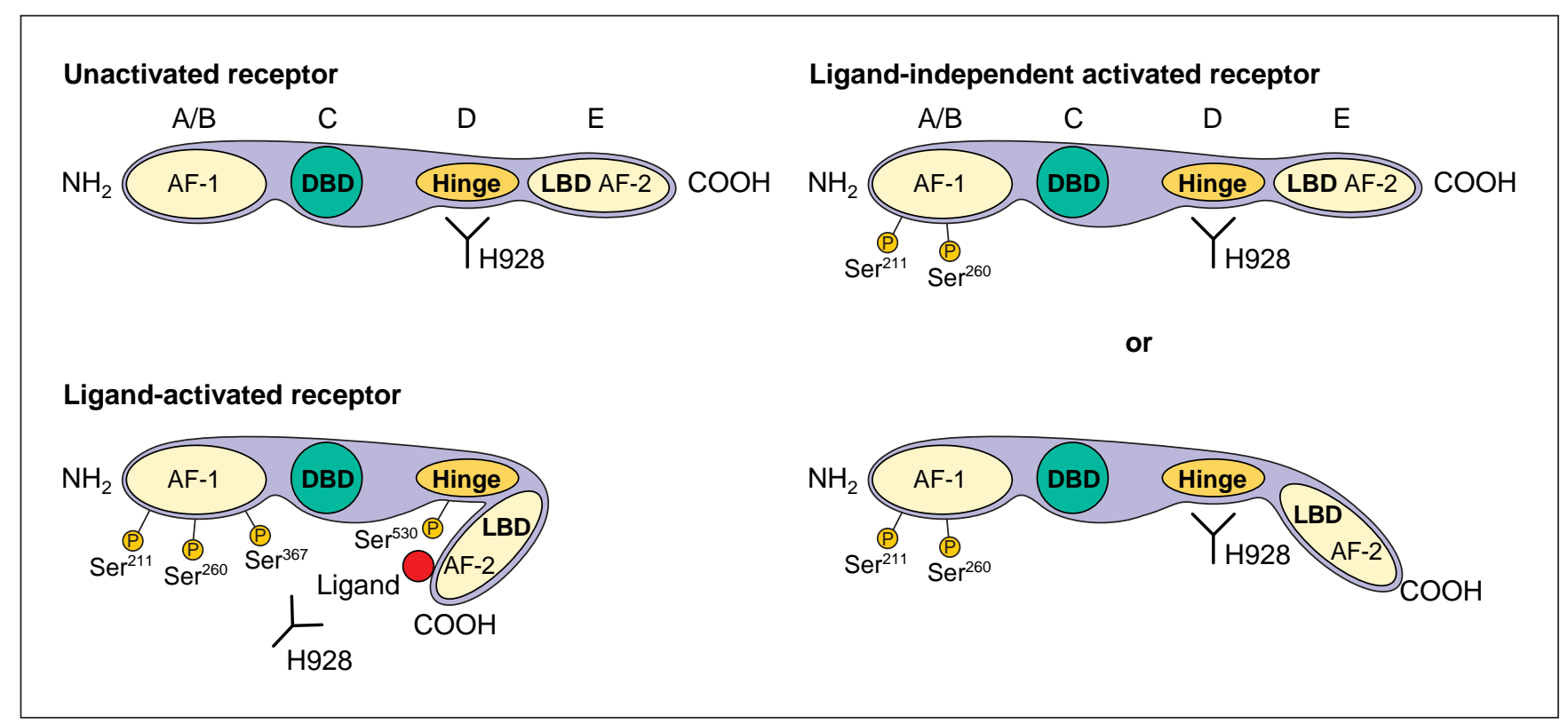

Fig. 4. Influence of ligand versus ligand-independent activation of progestin receptors on H928 binding. In the absence of progesterone, the hinge region of the progestin receptor is recognized by the progestin receptor antibody, H928. In the presence of progesterone, the hinge region of the progestin receptor is not recognized by H928, probably as a result of a conformational change in the progestin receptor that obscures the hinge region after progesterone binding. When progestin receptors are activated via a ligand-independent mechanism, the progestin receptor either remains unaltered or assumes a slightly different conformation that allows the hinge region to be recognized by the $\mathrm{H} 928$ antibody. Alternatively, ligand-independently activated receptors may be recruited to the transcriptional complex in a manner that still allows $\mathrm{H} 928$ to gain access to the hinge region. The differential conformational state of progestin receptors may allow specific interactions with co-regulatory proteins, which may assemble to provide a unique transcriptional function. A/B, C, D and E: domains of the progestin receptor; AF-1: activation function 1 region; AF-2: activation function 2 region; COOH: C-terminal domain; DBD: DNA-binding domain; Hinge: hinge region; H928: $\mathrm{H} 928$ progestin receptor antibody; LBD: ligand-binding domain; $\mathrm{NH}_{2}$ : $\mathrm{N}^{-t e r m i n a l}$ domain; Ser: phosphorylated serine residue.

hypothalamic cell cultures (Lee et al., 1999), and these receptors appear to be constitutively active and to generate cAMP, which may lead to the activation of progestin receptors. Although oestradiol can activate progestin receptors ligand-independently to alter gonadotrophin secretion, oestradiol does not activate progestin receptors to alter behaviour. That is, oestradiol administered in high doses can increase lordosis but this increase is not blocked by the progestin antagonist RU486 (Blaustein et al., 1987).

\section{Do ligand and ligand-independent activated progestin receptors differ?}

As discussed above, the significance of ligand-independent activation of progestin receptors may be to induce a different functional outcome from that of ligand-activated progestin receptors. Support for this contention comes from studies using antibodies directed at particular sequences of the progestin receptor. One progestin receptor antibody, $\mathrm{H} 928$, is directed against the hinge region (corresponding to amino acids 523-536), a sequence common to both the A and B forms of the progestin receptor (Natraj and Richards, 1993; Park-Sarge et al., 1995). The affinity of H928 for progestin receptors is decreased by the presence of progesterone, indicating that ligand-bound receptors are not recognized by H928. That is, H928 immunoreactivity is decreased within the medial preoptic area and ventromedial hypothalamus $1 \mathrm{~h}$ after progesterone treatment (Auger et al., 2000b), probably as a result of a conformational change in the receptor after ligand activation, as ligand bound receptors are still recognized by another progestin receptor antibody (DAKO Corp., Carpinteria, CA) directed at a different region of the receptor (Auger et al., 2000b).

If mating stimuli, such as VCS, activate progestin receptors in the absence of progesterone, then it would be interesting to determine whether VCS also decreases $\mathrm{H} 928$ immunoreactivity. Although VCS decreased H928 immunoreactivity in the medial preoptic area of ovariectomized oestradiol-primed rats, VCS did not decrease H928 immunoreactivity within the forebrain of ovariectomizedadrenalectomized, oestradiol-primed rats. This finding indicates that when progestin receptors are activated by progesterone, a conformational change occurs so that the hinge region is not recognized by the $\mathrm{H} 928$ antibody. In contrast, the hinge region of progestin receptors activated by mating stimuli in the absence of progesterone either remains in or assumes a form that can still be recognized by 
the H928 antibody. Therefore, it is possible that progestin receptors undergo a particular conformational change depending on whether they are activated in a liganddependent or ligand-independent manner (Fig. 4). Whether the differential conformational state of progestin receptors is involved in the unique regulation of specific genes or behaviour remains to be tested. If activation of progestin receptors by mating stimuli occurs in the absence of progesterone, then it is meaningful to determine whether the effects of this activation on behaviour are similar to those that occur when the receptor is activated by progesterone. Some outcomes that appear to be dependent upon progesterone in oestradiol-primed female rats are proceptive behaviours, such as ear wiggling, hopping and darting behaviour (Blaustein and Olster, 1989).

\section{Is there a role for progesterone that is synthesized de novo in the brain?}

Both the ovaries and adrenal glands synthesize progesterone but little attention is given to the role of progesterone that is synthesized locally within the brain. Rats that have been ovariectomized and adrenalectomized still have low but detectable concentrations of progesterone within the brain (Corpechot et al., 1993). Neurotransmitters or mating stimuli that increase sexual behaviour may alter the synthesis or release of neurally derived progesterone, indicating that 'ligand-independent' activation of progestin receptors might be mediated via locally derived progesterone. However, data collected in studies using the H928 antibody do not support this alternative hypothesis. If mating stimuli caused the release of neurally derived progesterone, then $\mathrm{H} 928$ immunoreactivity should be decreased after mating stimulation as a result of ligand binding to progestin receptors. Although VCS decreased H928 immunoreactivity in ovariectomized rats, VCS did not decrease $\mathrm{H} 928$ immunoreactivity in ovariectomizedadrenalectomized rats. These data indicate that neurally derived progesterone is not involved in mating-induced activation of progestin receptors, but further testing is needed to rule out this possibility.

\section{Conclusion}

Taken together, these data support the contention that cues normally experienced during mating can gain access to the brain, where they influence progestin receptor-dependent processes in the absence of progesterone. Therefore, environmental signals, such as photoperiodic, chemosensory and somatosensory stimuli, may influence steroid receptor-dependent processes in a ligand-independent manner. Although the data presented in this review focus on the role of ligand-independent activation of progestin receptors in modulating female sexual behaviour, it is likely that ligand-independent activation of steroid receptors affects other types of behaviour or physiological process, such as learning, aggression and developmental plasticity of neurones. Indeed, oestrogen, androgen, glucocorticoid and some orphan nuclear receptors are activated in a ligandindependent manner. It is not clear why there is an additional pathway to activate steroid receptors, although there may be several explanations for the functional relevance of ligand-independent activation of progestin receptors. (1) Ligand-independent activation of progestin receptors acts synergistically with progesterone. This contention has arisen from numerous studies showing that increased phosphorylation of proteins enhances ligand activation of progestin receptors. (2) Ligand-independent mechanisms are an important factor in ligand activation of progestin receptors. (3) Ligand-independently activated progestin receptors differ functionally from ligand activated receptors. (4) Ligand-independent mechanisms are involved in regulating the activity of different progestin receptor isoforms, resulting in different functional outcomes.

\section{References}

Key references are identified by asterisks.

Allen TO, Adler NT, Greenberg JH and Reivich M (1981) Vaginocervical stimulation selectively increases metabolic activity in the rat brain Science 211 1070-1072

Aronica SM and Katzenellenbogen BS (1993) Stimulation of estrogen receptor-mediated transcription and alteration in the phosphorylation state of the rat uterine estrogen Molecular Endocrinology 7 743-752

Auger AP, Moffatt CA and Blaustein JD (1996) Reproductively-relevent stimuli induce Fos-immunoreactivity within progestin receptorcontaining cells in localized regions of rat forebrain Journal of Neuroendocrinology 8 831-838

*Auger AP, Moffatt CA and Blaustein JD (1997) Progesterone-independent activation of rat brain progestin receptors by reproductive stimul Endocrinology 138 511-514

*Auger AP, Tetel MJ and McCarthy MM (2000a) Steroid receptor coactivator-1 (SRC-1) mediates the development of sex-specific brain morphology and behavior Proceedings of the National Academy of Sciences USA 97 7551-7555

Auger AP, LaRiccia LM, Moffatt CA and Blaustein JD (2000b) Progesterone, but not progesterone-independent activation of progestin receptors by a mating stimulus, rapidly decreases progestin receptor immunoreactivity in female rat brain Hormones and Behavior 37 135-144

Bai W, Rowan BG, Allgood VE, O'Malley BW and Weigel NL (1997) Differential phosphorylation of chicken progesterone receptor in hormone-dependent and ligand-independent activation Journal of Biological Chemistry $27210457-10463$

Bennett AL, Blasberg ME and Blaustein JD (2001) Sensory cues mediating mating-induced potentiation of sexual receptivity in female rats Hormones and Behavior 40 77-83

Beyer C, Gonzalez-Flores O and Gonzalez-mariscal G (1997) Progesterone receptor participates in the stimulatory effect of $\mathrm{LHRH}$, prostaglandin E2, and cyclic AMP on lordosis and proceptive behaviors in rats Journal of Neuroendocrinology 9 609-614

Blaustein JD and Olster DH (1989) Gonadal steroid hormone receptors and social behaviors. In Advances in Comparative and Environmental Physiology pp 31-104 Ed. J Balthazart. Springer-Verlag, Berlin

Blaustein JD, Finkbohner R and Delville Y (1987) Estrogen-induced and estrogen-facilitated female rat sexual behavior is not mediated by progestin receptors Neuroendocrinology 45 152-159

Boyson SJ, McGonigle P and Molinoff PB (1986) Quantitative autoradiographic localization of the D1 and D2 subtypes of dopamine receptors in rat brain Journal of Neuroscience 6 3177-3188

Chauchereau A, Cohen-Solal K, Jolivet A, Bailly A and Milgrom E (1994) Phosphorylation sites in ligand-induced and ligand-independent activation of the progesterone receptor Biochemistry 33 13 295-13 303

Chu HP, Morales JC and Etgen AM (1999) Cyclic GMP may potentiate 
lordosis behaviour by progesterone receptor activation Journal of Neuroendocrinology 11 107-113

Conneely OM, Maxwell BL, Toft DO, Schrader WT and O'Malley BW (1987) The A and B forms of the chicken progesterone receptor arise by alternate initiation of translation of a unique mRNA Biochemical and Biophysical Research Communications 149 493-501

Corpechot C, Young J, Calvel M et al. (1993) Neurosteroids: $3 \alpha$-hydroxy$5 \alpha$-pregnan-20-one and its precursors in the brain, plasma, and steroidogenic glands of male and female rats Endocrinology 133 1003-1009

Denner LA, Weigel NL, Maxwell BL, Schrader WT and O'Malley BW (1990) Regulation of progesterone receptor-mediated transcription by phosphorylation Science 250 1740-1743

Edwards DP, Weigel NL, Nordeen SK and Beck CA (1993) Modulators of cellular protein phosphorylation alter the trans-activation function of human progesterone receptor and the biological activity of progesterone antagonists Breast Cancer Research and Treatment 27 41-56

Foreman MM and Moss RL (1977) Effects of subcutaneous injection and intrahypothalamic infusion of releasing hormones upon lordotic response to repetitive coital stimulation Hormones and Behavior 8 219-234

Foreman MM and Moss RL (1979) Role of hypothalamic dopaminergic receptors in the control of lordosis behavior in the female rat Physiology and Behavior 22 283-289

Guerra-Araiza C, Cerbon MA, Morimoto S and Camacho-Arroyo I (2000) Progesterone receptor isoforms expression pattern in the rat brain during the estrous cycle Life Sciences 66 1743-1752

Hardy DF and Debold JF (1973) Effects of repeated testing on sexual behavior of the female rat Journal of Comparative and Physiological Psychology 85 195-202

Kato J, Hirata S, Nozawa A and Mouri N (1993) The ontogeny of gene expression of progestin receptors in the female rat brain Journal of Steroid Biochemistry and Molecular Biology 47 173-182

Kazmi SMI, Visconti V, Plante RK, Ishaque A and Lau C (1993) Differential regulation of human progesterone receptor-a and receptor-b formmediated trans-activation by phosphorylation Endocrinology 133 $1230-1238$

Knox KL, Ringstrom SJ, Szabo M, Perlyn CA, Sutandi S and Schwartz NB (1996) RU486 on an estrogen background blocks the rise in serum follicle-stimulating hormone induced by antiserum to inhibin or ovariectomy Endocrinology 137 1226-1232

Kuiper GGJM, Enmark E, Peltohuikko M, Nilsson S and Gustafsson JA (1996) Cloning of a novel estrogen receptor expressed in rat prostate and ovary Proceedings of the National Academy of Sciences USA 93 5925-5930

Lee D, Dong P, Copolov D and Lim AT (1999) D5 dopamine receptors mediate estrogen-induced stimulation of hypothalamic atrial natriuretic factor neurons Molecular Endocrinology 13 344-352

Levey AI, Hersch SM, Rye DB, Sunahara RK, Niznik HB, Kitt CA, Price DL, Maggio R, Brann MR and Ciliax BJ (1993) Localization of D1 and D2 dopamine receptors in brain with subtype-specific antibodies Proceedings of the National Academy of Sciences USA 90 8861-8865

Levine JE (1997) New concepts of the neuroendocrine regulation of gonadotropin surges in rats Biology of Reproduction 56 293-302

McKenna NJ, Xu J, Nawaz Z, Tsai SY, Tsai MJ and O'Malley BW (1999) Nuclear receptor coactivators: multiple enzymes, multiple complexes, multiple functions Journal of Steroid Biochemistry and Molecular Biology 69 3-12

*Mani SK, Allen JMC, Clark JH, Blaustein JD and O'Malley BW (1994a) Convergent pathways for steroid hormone- and neurotransmitterinduced rat sexual behavior Science 265 1246-1249

Mani SK, Allen JMC, Rettori V, Mccann SM, O'Malley BW and Clark JH (1994b) Nitric oxide mediates sexual behavior in female rats Proceedings of the National Academy of Sciences USA 91 6468-6472

*Mani SK, Fienberg AA, O'Callaghan JP, Snyder GL, Allen PB, Dash PK, Moore AN, Mitchell AJ, Bibb J, Greengard P and O'Malley BW (2000) Requirement for DARPP-32 in progesterone-facilitated sexual receptivity in female rats and mice Science 287 1053-1056
Mani SK, Mitchell A and O'Malley BW (2001) Progesterone receptor and dopamine receptors are required in delta 9-tetrahydrocannabinol modulation of sexual receptivity in female rats Proceedings of the National Academy of Sciences USA 98 1249-1254

Matuszewich L, Lorrain DS and Hull EM (2000) Dopamine release in the medial preoptic area of female rats in response to hormonal manipulation and sexual activity Behavioral Neuroscience $\mathbf{1 1 4}$ 772-782

Meredith JM, Moffatt CA, Auger AP, Snyder GL, Greengard P and Blaustein JD (1998) Mating-related stimulation induces phosphorylation of dopamine- and cyclic AMP-regulated phosphoprotein-32 in progestin receptor-containing areas in the female rat brain Journal of Neuroscience 1810 189-10 195

Mulac-Jericevic B, Mullinax RA, Demayo FJ, Lydon JP and Conneely OM (2000) Subgroup of reproductive functions of progesterone mediated by progesterone receptor-B isoform Science 289 1751-1754

Natraj U and Richards JS (1993) Hormonal regulation, localization, and functional activity of the progesterone receptor in granulosa cells of rat preovulatory follicles Endocrinology 133 761-769

Park-Sarge OK, Parmer TG, Gu Y and Gibori G (1995) Does the rat corpus luteum express the progesterone receptor gene? Endocrinology 136 $1537-1543$

Pfaff D and Keiner M (1973) Atlas of estradiol-concentrating cells in the central nervous system of the female rat Journal of Comparative Neurology 151 121-158

*Pfaff DW, Schwartzgiblin S, McCarthy MM and Kow LM (1994) Cellular and molecular mechanisms of female reproductive behaviors Physiology of Reproduction 2nd Edn Vols 1 and 2 107-220

Pfaus JG, Kleopoulos SP, Mobbs CV, Gibbs RB and Pfaff DW (1993) Sexual stimulation activates $\mathrm{C}-\mathrm{f}$ - within estrogen-concentrating regions of the female rat forebrain Brain Research 624 253-267

Power RF, Mani SK, Codina J, Conneely OM and O'Malley BW (1991a) Dopaminergic and ligand-independent activation of steroid hormone receptors Science 254 1636-1639

Power RF, Lydon JP, Conneely OM and O'Malley BW (1991b) Dopamine activation of an orphan of the steroid receptor superfamily Science $\mathbf{2 5 2}$ 1546-1548

Reading DS and Blaustein JD (1984) The relationship between heat abbreviation and neural progestin receptors in female rats Physiology and Behavior 32 973-981

Rowan BG, Garrison N, Weigel NL and O'Malley BW (2000) 8-Bromocyclic AMP induces phosphorylation of two sites in SRC-1 that facilitate ligand-independent activation of the chicken progesterone receptor and are critical for functional cooperation between SRC- 1 and CREB binding protein Molecular and Cellular Biology 20 8720-8730

Shaikh AA and Shaikh SA (1975) Adrenal and ovarian steroid secretion in the rat estrous cycle temporally related to gonadotropins and steroid levels found in peripheral plasma Endocrinology 96 37-44

Shughrue PJ, Lane MV and Merchenthaler I (1997) Comparative distribution of estrogen receptor-alpha and -beta mRNA in the rat central nervous system Journal of Comparative Neurology 388 507-525

Simerly RB, Chang C, Muramatsu M and Swanson LW (1990) Distribution of androgen and estrogen receptor mRNA-containing cells in the rat brain: an in situ hybridization study Journal of Comparative Neurology 294 76-95

Tetel MJ, Getzinger MJ and Blaustein JD (1993) Fos expression in the rat brain following vaginal-cervical stimulation by mating and probing Journal of Neuroendocrinology 5 397-404

Tora L, Gronemeyer H, Turcotte B, Gaub M-P and Chambon P (1988) The $\mathrm{N}$-terminal region of the chicken progesterone receptor specifies target gene activation Nature 333 185-188

Walaas SI and Greengard P (1984) DARPP-32, a dopamine- and adenosine $3^{\prime}: 5^{\prime}$-monophosphate-regulated phosphoprotein enriched in dopamineinnervated brain regions I. Regional and cellular distribution in the rat brain Journal of Neuroscience 4 84-98

Zhou D, Apostolakis EM and O'Malley BW (1999) Distribution of D(5) dopamine receptor mRNA in rat ventromedial hypothalamic nucleus Biochemical and Biophysical Research Communications 266 556-559 